\title{
Xanthogranuloma of the choroid plexus of the third ventricle: case report and literature review
}

\author{
P. Miranda; R.D. Lobato; J.R. Ricoy*; A. Lagares y A. Ramos**
}

Servicios de Neurocirugía, Neuropatología* y Neurorradiología**. Hospital 12 de Octubre. Madrid

\section{Summary}

Xanthogranulomas of the choroids plexus (XG) are benign tumours of debatable etiology which become rarely symptomatic. Only few cases have been studied with MRI. A new case of xanthogranuloma of the third ventricle showing unusual features in the $C T$ and MRI studies in a 47-year-old man with a 2-month history of gait and urinary disturbances and cognitive impairment is reported. The literature concerning clinical and neuroradiological presentation of intracranial xanthogranulomas is reviewed.

KEY WORDS: Xanthogranuloma. Third ventricle tumour. MRI

Xantogranuloma del plexo coroideo del tercer ventriculo: descripción de un caso y revisión de la literatura

\section{Resumen}

El xantogranuloma del plexo coroideo es un tumor benigno de etiología desconocida que raramente produce síntomas. Su comportamiento en los estudios de resonancia magnética se ha descrito en pocas ocasiones y no está bien definido. Presentamos un nuevo caso de xantogranuloma del tercer ventriculo con caraterísticas atípicas en los estudios de CT y RM craneal en un paciente de 47 años y una clínica de $\mathbf{2}$ meses de evolución de alteración de la marcha y deterioro cognitivo. Igualmente, se revisa la literatura existente respecto a la presentación clínica y radiológica de estos tumores.

PALABRAS CLAVE: Xantogranuloma. Tumor de tercer ventrículo. RM

\section{Introduction}

XG are benign tumours typically composed of large foam-filled cells with clusters of lymphocytes and macrophages associated to cholesterol clefts. XG rarely cause neurological dysfunction ${ }^{3,13,15}$. With few exceptions, they constitute incidental autopsy findings almost always restricted to the choroid plexus of the lateral ventricles ${ }^{21}$. Obstruction of the ventricular system has been reported infrequently. Etiology is still debatable ${ }^{17}$. We report a new case of symptomatic XG of the third ventricle studied with CT and MRI and showing some particular histopathological and neuroradiological features.

\section{Case report}

A 47-year-old man was admitted with a 2-month history of gait instability and urinary disturbances, consisting in occasional loss of sphincterian control and short-term memory deficits. The symptoms had developed insidiously and the patient did not suffer headache, vomiting or loss of visual acuity.

Physical and routine laboratory examinations, including serum cholesterol determinations, were normal. Neurological examination revealed disturbance of recent memory and cognitive impairment. Fundoscopy was normal. He scored $24 / 30$ on minimental test. Short stepped gait and intentional tremor were also observed.

Cranial CT scan showed a $2 \times 2 \times 1 \mathrm{~cm}$ oval shaped lesion located in area of the third ventricle obstructing the foramina of Monro and causing biventricular hydrocephalus. The lesion was heterogeneous appearing partly hypodense and hyperdense, with hyperdense areas corresponding to calcification. Following contrast injection the lesion showed partial enhancement. There was associated edema in the basal ganglia of the left cerebral hemisphere (Figure $1)$.

Cranial MRI revealed the lesion in the region of third ventricle and hypothalamic area. It was located mainly extraventricularly, spreading between the fornices, oc-

Abbreviations. CT: computarized tomography. XG: xantogranuloma. MRI: magnetic resonance imaging 


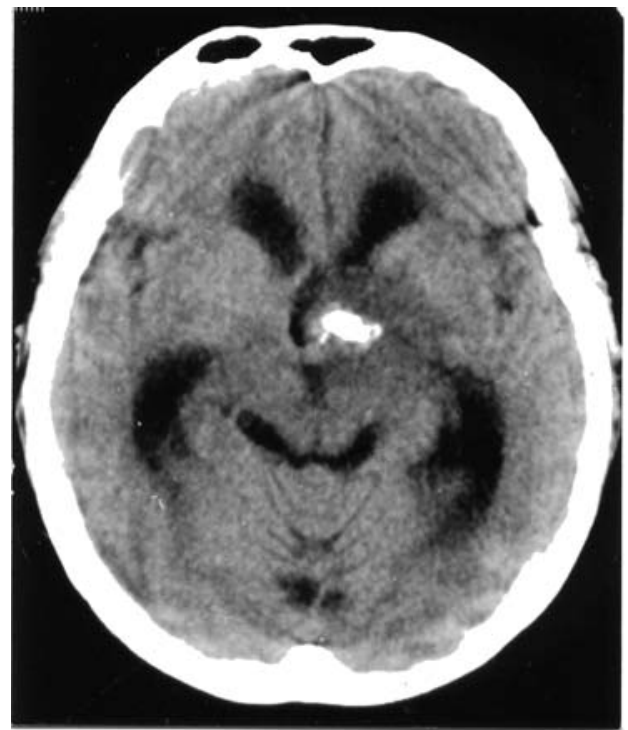

Figure 1. Preoperative CT scan. A rounded mass in the region of the third ventricle, slightly hyperdense with of calcification obstructing the foramina of Monro is seen. Surrounding brain edema and obstructive hydrocephalus can also be appreciated.

cluding both foramina of Monro and causing bilateral hydrocephalus. It was heterogeneous in appearance being isointense in pT1 sequences and hyperintense in pT2 images, showing haemosiderin deposits and calcification. Important hyperintensity extending into the left basal ganglia region suggestive of edema was also observed. Following gadolinium administration it showed partial enhancement (Figure 2).

The patient was operated through a transcallosal approach. The left foramen of Monro appeared deformated by a brown yellowish subependymal lesion adhered to the body of the left fornix. Total excision preserving both fornices was achieved. Histopathological examination revealed a lesion composed of foamy cells in relation to vascular lines corresponding to choroids plexus showing changes secondary to haemorrhage and fibrosis which would explain the absence of the typical epithelial covering of the choroid plexus. The histological diagnosis was xanthogranuloma (Figure 3).

Postoperative MRI control showed disappearance of perilesional edema and mass effect observed preoperatively (Figure $2 \mathrm{~d}$ ). Because of moderate neurological deterioration and persistent ventricular enlargement, a medium pressure ventriculoperitoneal shunt had to be implanted. Six months after surgery both gait and memory as well as urinary sphincterian control were normal and the patient returned to his normal daily activities working as a fulltime university professor.

\section{Discussion}

$\mathrm{XG}$ are benign tumours typically composed of cholesterol clefts, macrophages (xanthoma cells), chronic inflammatory cellular reaction and haemosiderin deposits. XG were firstly described by Blumer in $1900^{2}$ and since then

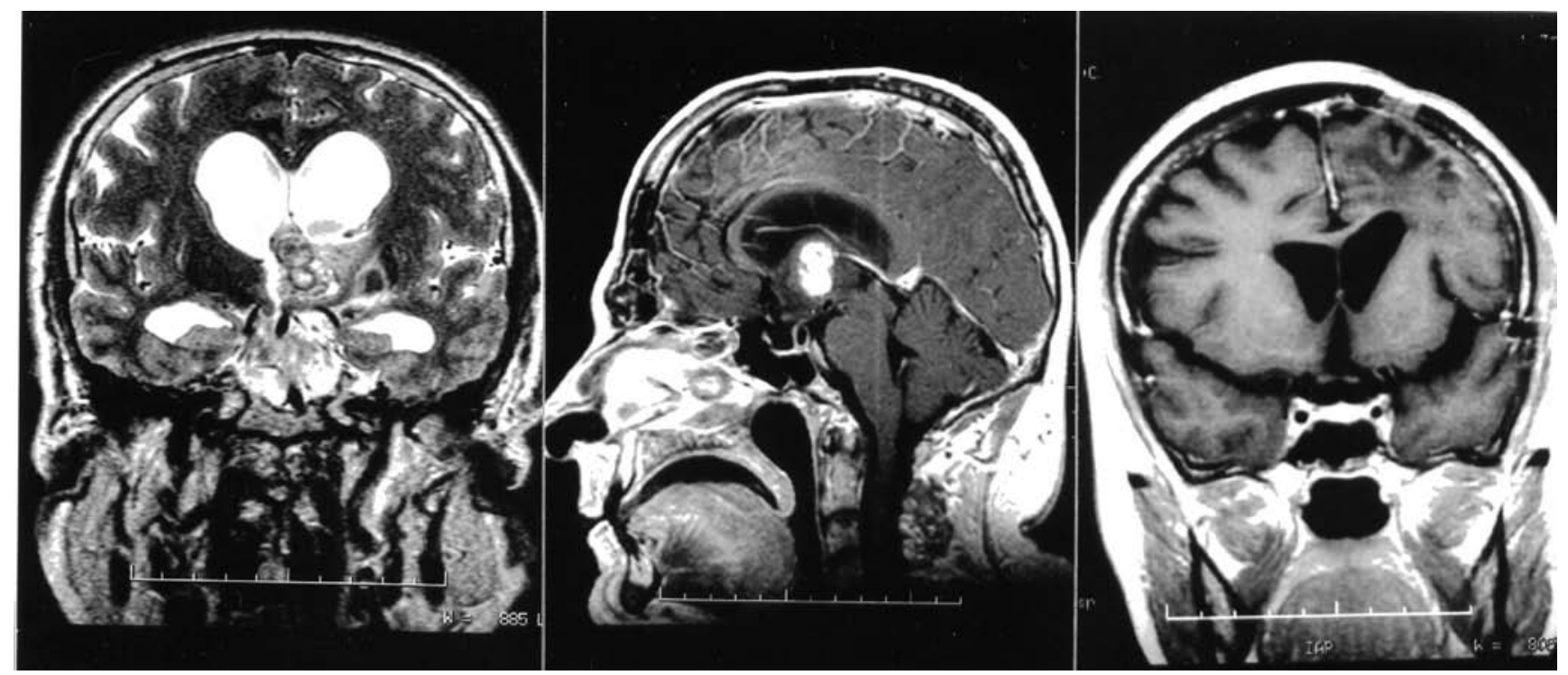

Figure 2. Left: Preoperative MRI, T2-weighted coronal image showing an heterogeneous lesion that presents areas of previous hemorrhage and associates edema spreading through the left basal ganglia. Middle. Preoperative MRI, TI -weighted sagittal image after gadolinium injection showing an oval shaped lesion in the area of the third ventricle and hypothalamic area that enhances heterogeneously. Right: Postoperative MRI control shows abscence of both tumor and perifocal edema. 


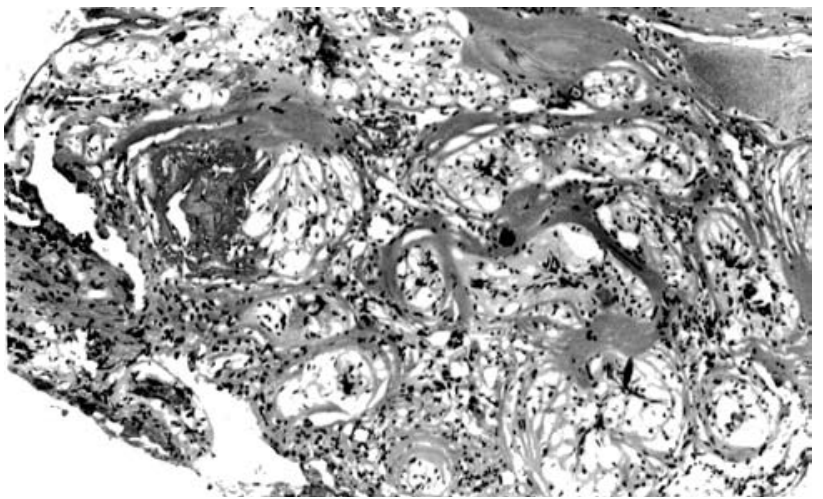

Figure 3. Microphotograps of the tumor showing A) Coalescent papillary structures with clear centers and areas of hemmorrhage and calcification. H/E x100; B) Clear papillary structures with foamy cells surrounded by fibrous reaction and inflammatory infiltrates. H/E x200; C) Detail of a papillary structure with a central vessel, surrounded by lipid-laden cells. H/E $x 400$.

they have been found incidentally in 1.6 to $7 \%$ of the cases in autopsy series ${ }^{19}$. XG are more frequent in the lateral ventricles where they usually remain asymptomatic because they are too small to obstruct the CSF flow. By contrast, those found in the third ventricle are more commonly symptomatic.

Fifteen cases of XG of the lateral ventricles have been reported and the most frequent localization was the glomus of the choroid plexus. Among the sixteen cases of $\mathrm{XG}$ located in the third ventricle reported up to date $1,6,8,10-15,17,18,20$ only four were studied with MRI ${ }^{17,18,20}$. XG of the fourth ventricle are exceptional ${ }^{19}$.

Pathogenesis of $\mathrm{XG}$ is still a matter of controversy ${ }^{18}$. Brück et al reviewed the literature and found that all asymptomatic XG and 6 out of 7 symptomatic XG of the lateral ventricles had the typical histological features described above. In contrast, lesions in the third ventricle were often cystic and epithelium-lined, or appeared associated to colloid cysts ${ }^{3}$. Thus some authors believe that at the origin, a neuroepithelial cyst is formed which may evolve either to a colloid cyst, to a XG or to intermediate forms ${ }^{3,13,14}$. However, the total absence of epithelial and cystic components as occurred in our patient, has been reported previously ${ }^{18}$. Inflammatory response to the invagination and proliferation of the choroid plexus may be the pathogenic mechanism in these cases, as it happens in $\mathrm{XG}$ of the lateral ventricles ${ }^{5,21}$.

Table 1

Histopathologic findings in cases of XG of the third ventricle

\begin{tabular}{|c|c|c|c|c|c|}
\hline $\begin{array}{l}\text { Case } \\
\text { number }\end{array}$ & Author (year) & $\begin{array}{l}\text { Foamy cefs, inflammatory infiltrate, } \\
\text { hemorrhage or calcificaction }\end{array}$ & Cystic component & Mixed XG and colloid cyst & $\begin{array}{l}\text { Epithelial } \\
\text { component }\end{array}$ \\
\hline 1 & Jaer et al. (1973) & + & + & + & + \\
\hline 2 & $\begin{array}{l}\text { Shuangshoti et al. } \\
(1975)\end{array}$ & + & + & + & + \\
\hline 3 & Rush et al. (1979) & + & + & NS & NS \\
\hline 4 & Rush et al. (1979) & + & + & NS & NS \\
\hline 5 & Szper et al. (1979) & + & + & - & + \\
\hline 6 & Goderskyet al. (1980) & + & + & NS & NS \\
\hline 7 & Antunes et al. (1981) & + & + & + & + \\
\hline 8 & Antunes et al. (1981) & + & + & + & + \\
\hline 9 & $\begin{array}{l}\text { Matsushima et al. } \\
(1985)\end{array}$ & + & + & + & + \\
\hline 10 & $\begin{array}{l}\text { Razavi-Encha et al. } \\
(1987)\end{array}$ & + & + & + & + \\
\hline 11 & Wiot et al. (1989) & NS & NS & NS & NS \\
\hline 12 & Montaldi et al. (1989) & + & NS & - & - \\
\hline 13 & Montaldi et al. (1989) & + & NS & - & + \\
\hline 14 & Tatter et al. (1994) & + & + & - & + \\
\hline 15 & Tatter et al. (1994) & + & + & - & + \\
\hline 16 & Tomita et al. (1996) & + & - & - & - \\
\hline 17 & Present case $(2005)$ & + & - & - & - \\
\hline
\end{tabular}


Table 2.

CT appearance of symptomatic XG of the third ventricle

\begin{tabular}{|l|l|c|c|}
\hline Case no. & Plain CT sean & Hypodense central arca & Contrast enhacement \\
\hline 1 (Rush 1979) & Hyperdense & - & - \\
\hline 2 Rush 1979) & Hyperdense & - & - \\
\hline 3 Szper (1979) & Hyperdense & + & + \\
\hline 4 Godersky (1980) & NS & + & + \\
\hline 5 Antunes (1981) & NS & + & + \\
\hline 6 Antunes (1981) & Dense & + & + \\
\hline 7 Razavi Encha (1987) & NS & - & + \\
\hline 8 Wiot (1989) & Hypodense & - & + \\
\hline 9 Montaldi (1989) & Hypoisodense & - & - \\
\hline 10 Montaldi (1989) & Hypoisodense & - & NS \\
\hline 11 Tatter $(1994)$ & Isoodense & - & - \\
\hline 12 Tatter (1994) & Isodense & - & - \\
\hline 13 Tomita (1996) & lso-hyperdense & & + \\
\hline 14 Present case & Hyperdense & & + \\
\hline
\end{tabular}

NS: Not specified

Table 3.

MRI appearance of symptomatic XG of the third ventricle

\begin{tabular}{|c|c|c|c|c|}
\hline Case no. & pT1 sequences & pT2 sequences & Gadolinium enhacement & Others \\
\hline 8 & Hyperintense & Hyperintense & NS & \\
\hline 11 & Hyperintense & Hyperintense & Intermittent rim & \\
\hline 12 & Isointense & Hyperintense & Intermittent rim & \\
\hline 13 & Hyperintense & $\begin{array}{l}\text { Hyperintense } \\
\text { (peripherally } \\
\text { hypointense) }\end{array}$ & $\mathrm{NS}$ & $\begin{array}{l}\text { Areas suggestive of subacute } \\
\text { intracerebral haematoma }\end{array}$ \\
\hline 14 & Isointense & Hyperintense & Heterogeneous & Edema in basal ganglia \\
\hline
\end{tabular}

NS: Not specified

These forms of XG of the third ventricle may exhibit higher rates of additional pathological changes, such as inflammatory cell infiltration or intralesional haemorrhage. A primary intracerebral origin unrelated to the epithelium of the choroid plexus of the third ventricle can not be excluded, although this possibility seems much less likely. However, a case of multicentric parenchymal xanthogranuloma in a child has been recently reported and the authors suggested that the lesion had a developmental origin ${ }^{9}$. The main histological characteristics of the cases of XG of the third ventricle reported up to date are summarized in Table 1.

In the CT scan studies, XGs of the third ventricle have been found to be oval and smooth walled making them indistinguishable from colloid cysts. In addition, and also like colloid cysts, XG may show different CT densities, varying from hyper-to hypodense in comparison to brain tissue (Table 2). In the four cases of XG of the third ventricle studied with MRI they appeared iso-hyperintense in pT1 and hyperintense in pT2 sequences, probably because of high solid lipidic components ${ }^{15}$, and they enhanced following gadolinium administration (Table 3). Brain edema related to XG had been previously reported in one case of the lateral ventricles ${ }^{4}$ but this is the first case of XG of the third ventricle showing associated brain edema demonstrated with MRI.

$\mathrm{XG}$ in our patient shows the particularities of being subependymal in location and mainly extraventricular, histologically unrelated to the choroidal epithelium or a colloid cyst, and producing large areas of edema in the basal ganglia. All these factors support a primary origin of the 
lesion out the third ventricle without apparent relation to a previous neuroepithelial or colloid cyst.

\section{References}

1. Antunes, J.I., Kvam, K., Ganti, S.R., Louis, K.M., Goodman, J.: Mixed colloid cystsxanthogranulomas of the third ventricle. Surg Neurol 1981; 16: 256-261.

2. Blumer, G.: Bilateral cholesteotomatous endothelioma of the choroid plexus. Johns Hopkins Hosp. Rep., 1900; 9: 279-290.

3. Bruck, W., Sander, U., Blacjenberg, P., Friede, R.L.: Symptomatic xanthogranuloma of the choroid plexus with unilateral hydrocephalus. Case report. J Neurosurg 1991; 75: 32-327.

4. Doernbach, J.: Uber cystische und zellige Geschwülste der Hirnventrikel. [Virchows Arch] 1948; 316: 51-75.

5. Gaskill, S.J., Saldivar, V., Rutman, J., Marlin, A.E.: Giant bilateral xanthogranulomas in a child: case report. Neurosurgery 1992; 31: 114-117.

6. Godersky, J.C., Rockswold, G., Larson, D.A.: Xanthogranuloma of the third ventricle producing hydrocephalus. Neurosurgery 1980; 7: 68-70.

7. Handagoon, P., Pitakdamrongwong, N., Shuangshoti, S.: Xanthogranulomas of choroid plexus. Neuroradiology 1987; 29: 172-173.

8. Jaer, O., Loken, A., Nesbakken, R.: Hydrocephalus due to xanthogranuloma: case report. J Neuosurg 1973; 39: 659661.

9. Lesniak, Ms., Viglione, M.P., Weingart, J.: Multicentric parenchymal xanthogranuloma in a child: case report and review of the literature. Neurosurgery 2002; 51: 1493-1498.

10. Matshushima, T., Fukui, M., Kitamura, J., Soejima, T., Ohta, M., Okano, H.: Mixed colloid cyst-xanthogranuloma of the third ventricle. A light and electron microscopic study. Surg Neurol 1985; 24: 457-462.

11. Montaldi, S., Deruaz, J.P., Cai, Z.T., de Tribolet, N.: Symptomatic xanthogranuloma of the third ventricle. Report of two cases and review of the literature. Surg Neurol 1989; 32: 200-205.

12. Razavi-Encha, F., Gray, F., Gaston, A., Gherardi, R.,
Caron, J.P., Poirier, J.: Symptomatic xanthogranuloma of the choroid plexus of the third ventricle. A new case with ultraestructural study. Surg Neurol 1987; 6: 569-574.

13. Rush, J.L., Kusske, J.A., Porter, R.W., Pribram, H.W.: Xanthogranulomas of the third ventricle. Neurosurgery 1979; 4: 329-33.

14. Shuangshoti, S., Phonprasert, C., Suwanwela, N., Netsky, M.G.: Combined neuroepithelial (colloid) cyst and xanthogranuloma (xanthoma) in the third ventricle. Neurology 1975; 25: 547-552.

15. Szper, I., Oi, S., Leestma, J., Kim, K.S., Wetzel, N.E.: Xanthogranuloma of the third ventricle: case report. J Neurosurg 1979; 51: 565-568.

16. Tada, M., Koiwa, M., Chono, Y., Nemoto, M., Kashiwaba, T., Abe, H., Miyasaka, K.: Neuroepithelial (colloid) cyst of the cerebellar vermis containing a xanthogranuloma. Am J Neuroradiol 1993; 14: 951-953.

17. Tatter, S.B., Ogilvy, C.S., Golden, J.A., Ojemann, R.G., Louis, D.N.: Third ventricular xanthogranulomas clinically and radiologically mimicking colloid cysts. Report of two cases. J Neurosurg 1994; 81: 605-609.

18. Tomita, H., Tamaki, N., Korouse, K., Kokunai, T.: Xanthogranuloma with massive hematoma in the third ventricle: case report. Neurosurgery 1996; 39: 591-594.

19. Vaquero, J., Leunda, G., Cabezudo, J.M., De Juan, M., Herrero, J., Bravo, G.: Posterior fossa xanthogranuloma: case report. J Neurosurg 1979; 51: 718-722.

20. Wiot, J.G., Lukin, R., Tomsick, T.A.: Xanthogranuloma of the third ventricle. Am J Neuroradiol 1989; 10: S57.

21. Wolf, A., Cowden, D., Graham, S.: Xanthomas of the choroid plexus in man. J Neuropathol Exp Neurol 1950; 9: 286-297.

Miranda, P.; Lobato, R.D.; Ricoy, J.R.; Lagares, A.; Ramos, A.: Xanthogranuloma of the choroid plexus of the third ventricle: case report and literature review. Neurocirugía 2005; 16: 518-522.

Correspondencia postal: P. Miranda. Servicio de Neurocirugía. Hospital 12 de Octubre. Avda. de Córdoba s/n. 28041 Madrid. Spain. 